\section{A Comparison of 13 Sweet Pepper Varieties under an Organic Farming System}

\author{
George E. Boyhan ${ }^{1}$, Cecilia McGregor ${ }^{1}$, Suzanne O’Connell ${ }^{1}$, \\ Johannah Biang ${ }^{1}$, and David Berle ${ }^{1}$
}

AdDitional INDEX wORDs. Capsicum annum, certified organic production, disease resistance, production cost, sustainable

\begin{abstract}
SUMMARY. There is a dearth of information on pepper (Capsicum annuum) variety production under organic conditions; therefore, a randomized complete block designed experiment of 13 pepper varieties were evaluated in 2016 and 2017 using organic production practices on land managed organically for the 6 previous years. Total yield, graded yield, and early yield were the main factors of interest. There were by-year interactions, so the data were analyzed separately for each year. All of the peppers evaluated except for 'Sweet Chocolate' were bell pepper types. The average total yield was 1229 and 1754 boxes/acre $(28 \mathrm{lb} /$ box $)$ in 2016 and 2017 , respectively. There were no statistically significant differences for total yield or early total yield in 2016. In 2017, the top five highest yielding varieties were Aristotle X3R ${ }^{\circledR}$, Gridiron, King Arthur, Flavorburst, and Blitz. With the exception of 'Flavorburst', all of these entries were among the highest yielding for fancy fruit ( $\geq 3$ inches diameter and 3.5 inches length). The greatest early yield in 2017 included 'Aristotle X3R ${ }^{\circledR}$, 'Flavorburst', 'Touchdown', 'Islander', and 'Gridiron'. In 2017, early yields of fancy fruit greater than 100 boxes/ acre included 'Aristotle X3R ${ }^{\circledR}$, 'Red Knight X3R ${ }^{\circledR}$ ', 'Blitz', and 'Gridiron'.
\end{abstract}

$\mathrm{I}$ n 2018, the United States produced almost 42,000 acres of bell peppers (Capsicum annuum), with four-fifths of this production aimed at the fresh market [U.S. Department of Agriculture (USDA), 2019]. Georgia produced 5548 acres in 2017, making it one the top three pepper-producing states (U.S. Food and Drug Administration, 2015; Wolfe and Stubbs, 2018). Although the current level of production of organic peppers in Georgia is small, the value of organic production overall in Georgia is more than $\$ 47$ million (USDA, 2017). There are few trials evaluating peppers under

Received for publication 11 July 2019. Accepted for publication 5 Nov. 2019.

Published online 9 December 2019

${ }^{1}$ University of Georgia, Department of Horticulture, 1111 Miller Plant Science Building, Athens, GA 30602-5004

We acknowledge the efforts of Yihua Chen, UGArden student workers, Robert Tate, Mallory Warren, and Jean Yost. Also, thank you to Sakata Seed and Seminis Vegetable Seeds for donating untreated seeds.

G.E.B is a Professor, Extension Vegetable Specialist.

C.M. and D.B. are Associate Professors.

S.O. is a Former Assistant Professor.

J.B. is a Senior Agricultural Specialist.

G.E.B. is the corresponding author. E-mail: gboyhan@ uga.edu.

This is an open access article distributed under the CC BY-NC-ND license (https://creativecommons.org/ licenses/by-nc-nd/4.0/).

https://doi.org/10.21273/HORTTECH04455-19 organic conditions; however, there are many such trials conducted under conventional production practices (Boyhan et al., 2015; Gahler and Hofelich, 2017; Oxley et al., 2016; Sideman, 2016).

Many studies involving organic pepper production are centered around evaluating fertility and comparisons to conventional production (Duman et al., 2018; Elmann et al., 2016; Jokela and Nair, 2016). There are only a handful of studies evaluating pepper varieties under organic production practices. Most organic pepper trials have compared some aspect of conventional and organic production and generally concluded that yields between the two types of systems can be comparable with appropriate cultural practices (Chellemi and Rosskopf, 2004; Delate et al., 2008; Juroszek and Tsai, 2009; Silva and Bruce, 2016). A Florida study found organic peppers yields could match statewide conventional yields

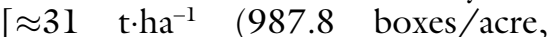
where 1 box $=28 \mathrm{lb})]$ when soil solarization practices were used (Chellemi and Rosskopf, 2004). An Iowa study compared multiple conventional and organic fertility programs for pepper (Delate et al., 2008). They found that organically grown 'Red Knight $\mathrm{X} 3 \mathrm{R}^{\circledR}$ ' pepper yields equaled or surpassed conventional yields $\left[\approx 26,000 \mathrm{~kg} \cdot \mathrm{ha}^{-1}(828.4\right.$ boxes/acre)] when $\left[56 \mathrm{~kg} \cdot \mathrm{ha}^{-1}(50.0\right.$ $\mathrm{lb} / \mathrm{acre})]$ of compost-based organic fertilizer or more was supplied. A study at the University of Wisconsin West Madison Agricultural Research Station, located in Verona, WI, involved six bell peppers and four roasting pepper varieties (Silva and Bruce, 2016). Variety Ace $F_{1}$ had the greatest number of fruit per plot, which was more than any of the other bell pepper varieties. There was no difference in total marketable fruit with a high percentage of unmarketable peppers $(>60 \%)$ across all entries. In another trial that primarily evaluated cropping system (i.e., conventional, organic, or soilless) there were two varieties, Almuden and Quito (Lopez et al., 2013). Conventional peppers generally resulted in larger, firmer, and thicker fruit, with 'Almuden' better suited for soilless production.

A study in Spain evaluated three pepper varieties under organic or conventional production and found no differences in the yields between the two systems, but did not directly

\begin{tabular}{llll}
\hline $\begin{array}{l}\text { Units } \\
\text { To convert U.S. to SI, } \\
\text { multiply by }\end{array}$ & U.S. unit & SI unit & $\begin{array}{l}\text { To convert SI to U.S., } \\
\text { multiply by }\end{array}$ \\
\hline 0.4047 & $\mathrm{acre}(\mathrm{s})$ & $\mathrm{ha}$ & 2.4711 \\
0.3048 & $\mathrm{ft}$ & $\mathrm{m}$ & 3.2808 \\
0.0929 & $\mathrm{ft}^{2}$ & $\mathrm{~m}^{2}$ & 10.7639 \\
3.7854 & $\mathrm{gal}$ & $\mathrm{L}$ & 0.2642 \\
2.54 & inch $(\mathrm{es})$ & $\mathrm{cm}$ & 0.3937 \\
0.4536 & $\mathrm{lb}$ & $\mathrm{kg}$ & 2.2046 \\
1.1209 & $\mathrm{lb} / \mathrm{acre}$ & $\mathrm{kg} \cdot \mathrm{ha}^{-1}$ & 0.8922 \\
0.0254 & $\mathrm{mil}(\mathrm{s})$ & $\mathrm{mm}$ & 39.3701 \\
1.6093 & mile $(\mathrm{s})$ & $\mathrm{km}$ & 0.6214 \\
1.6093 & $\mathrm{mph}$ & $\mathrm{km} \cdot \mathrm{h}^{-1}$ & 0.6214 \\
28.3495 & $\mathrm{oz}$ & $\mathrm{g}$ & 0.0353 \\
14.7868 & tablespoon $(\mathrm{s})$ & $\mathrm{cm}^{3}$ & 0.0676 \\
2.2417 & ton $(\mathrm{s}) / \mathrm{acre}$ & $\mathrm{t} \cdot \mathrm{ha}^{-1}$ & 0.4461 \\
$\left({ }^{\circ} \mathrm{F}-32\right) \div 1.8$ & ${ }^{\circ} \mathrm{F}$ & ${ }^{\circ} \mathrm{C}$ & $\left({ }^{\circ} \mathrm{C} \times 1.8\right)+32$
\end{tabular}


compare the varieties (GrageraFacundo et al., 2012). A Taiwanese study evaluated pepper varieties under tropical conditions with organic production practices (Juroszek and Tsai, 2009). Pepper varieties were evaluated during the wet-hot and dry-cool seasons with no differences between the entries during the hotwet season. During the cool-dry season, 'Andalus' had the largest total yield with yields statistically greater than three of the six entries in the trials. Marketable organic pepper yields from 37 to $46 \mathrm{t} \cdot \mathrm{ha}^{-1}$ were attained during the hot-wet season and 21 to $38 \mathrm{t} \cdot \mathrm{ha}^{-1}$ during the cooldry season, which were comparable to conventional yields attained for the same varieties in different locations.

With the growth of the organic market, there is interest in evaluating and/or developing varieties that are uniquely suited to organic production (Boyhan and Stone, 2016; Lammerts van Buren et al., 2011). Characteristics that would be desirable in organic production include resistance to biotic and abiotic stressors, including diseases, weeds, and insects as well as nutrient use efficiency, and high yields with good fruit quality (Lammerts van Buren et al., 2011). Pimenta et al. (2016) found in evaluating heritability of seven $\mathrm{F}_{1}$ hybrid pepper varieties that the characteristics under both organic and conventional production systems were highly heritable. A systems comparison study that included a conventional with irrigation site, a conventional without irrigation site, and an organic with irrigation site was conducted in New York (Wyatt et al., 2013). Disease resistance to Phytophthora capsici was evaluated along with yield for 12 bell pepper varieties, three of which were commercial varieties and nine were test hybrids. The varieties, Revolution and Paladin were the top performers for mean marketable yield in the organic system. In another study evaluating organic fertilizer sources, there were three different varieties of Serrano peppers, with Don Diego having the best performance (Castellanos et al., 2017). In Spain, 25 landraces and three commercial varieties were evaluated under organic production practices and five landraces were identified as potential varieties with good performance for organic growers (Gragera et al., 2008). In a unique study of 37 pepper accessions that were evaluated for bioactive compounds both under organic and conventional production was conducted in Spain (Ribes-Moya et al., 2018). Fully ripe fruit, under organic conditions, showed a greater amount of ascorbic acid and total phenolics compared with conventional production. There were also significant variety $\times$ ripening and variety $\times$ growing conditions, suggesting that some varieties may be better suited for organic production for the development of bioactive compounds.

In a study evaluating organic ties, Magali R and Magda Super with or without sunhemp (Crotalaria juncea) intercropping, and with and without branch pruning, it was found that 'Magali R' produced heavier and larger fruit compared with 'Magda Super' (Cesar et al., 2007). It was also found that intercropping sunhemp improved yield, whereas branch pruning reduced yield.

A description of the bell pepper varieties included in our study follows, and photos of the entries are shown in Fig. I with company descriptions in Table 1. 'Aristotle $\mathrm{X} 3 \mathrm{R}^{\circledR}$ ' is a popular commercial $\mathrm{F}_{1}$ hybrid variety in the southeastern United States that has good yields with disease resistance to Potato virus $\Upsilon$ (PVY) and some races of bacterial leaf spot (Xanthomonas campestris pv. vesicatoria) (Boyhan et al., 2015; Kemble, 2019). 'Blitz' is an early maturing variety with resistance to Tobacco mosaic virus (TMV), Tobacco production, two sweet pepper varie-

etch virus (TEV), and several races of bacterial leaf spot (Sakata Seed, 2018). 'Gridiron' is a hybrid bell pepper that is red at full maturity (Sakata Seed, 2018). It is noted for its resistance to TMV, several races of bacterial leaf spot and TEV. 'King Arthur' is an $\mathrm{F}_{1}$ hybrid pepper, red at maturity with resistance to bacterial leaf spot races 1 and 2, PYV, TEV, and TMV (Johnny's Selected Seed, 2019; Kemble, 2019). 'PS 09979325 $\mathrm{XlOR}^{\circledR}$, is an $\mathrm{F}_{1}$ hybrid with resistance to bacterial spot races 0 to 10 , as well as, Tobamovirus tolerance (Seminis Vegetable Seeds, 2018). 'Red Knight $\mathrm{X} 3 \mathrm{R}^{\circledR}$ ' pepper is similar to ' $\mathrm{King}$ Arthur' with resistance to bacterial leaf spot races 1 to 3 and PVY resistance (Johnny's Selected Seed, 2019). 'Touchdown' is an $F_{1}$ red pepper at maturity with resistance to TMV and bacterial spot races 0 to 5 and 7 to 9 (Sakata Seed, 2018).

'Flavorburst' is another $\mathrm{F}_{1}$ variety that is yellow/orange at full maturity (Johnny's Selected Seed, 2019). Another yellow/orange variety is Gourmet, which also has resistance to TMV (Johnny's Selected Seed, 2019). 'Islander' is an $\mathrm{F}_{1}$ hybrid bell pepper with resistance to TMV and is interesting in that it matures to purple, then yellow/orange, and finally red when fully mature (Johnny's Selected Seed, 2019).

Jupiter is an open-pollinated variety that is red at full maturity that has tolerance to TMV (Totally Tomatoes, 2019). An heirloom variety included

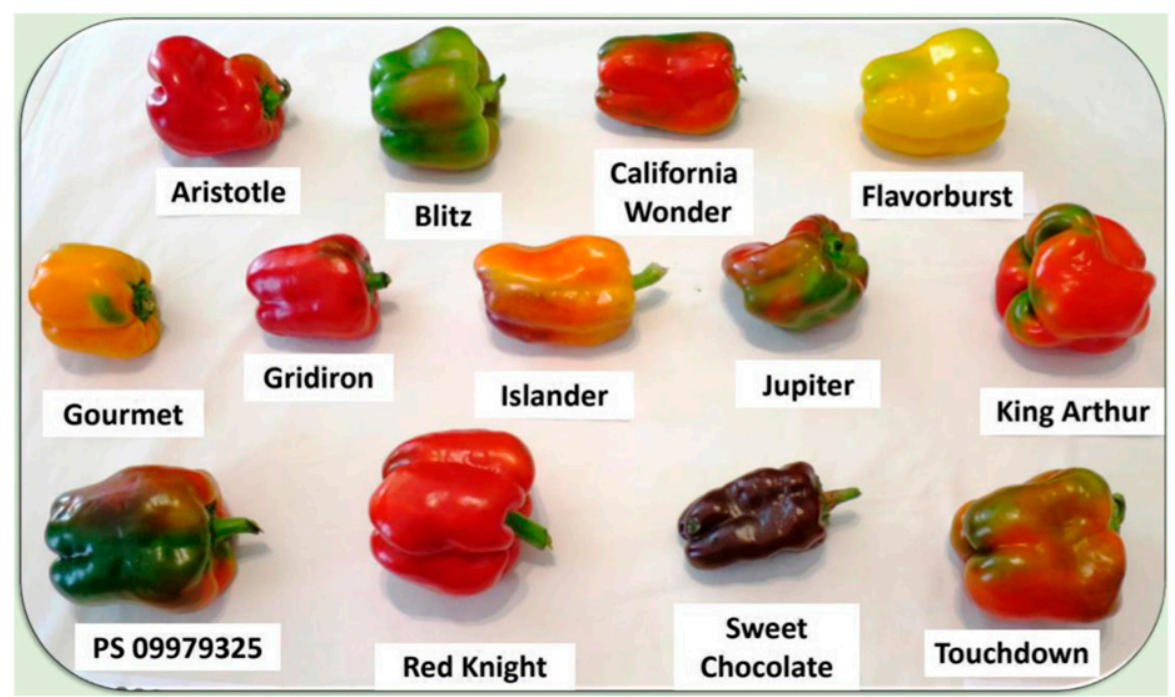

Fig. 1. Photographs of pepper varieties included in our study taken during the 2016 harvest. 
Table 1. Pepper variety characteristics as reported by the seed companies.

\begin{tabular}{|c|c|c|c|c|c|}
\hline Name & $\begin{array}{c}\text { Variety } \\
\text { type }\end{array}$ & Seed type & Qualities & $\begin{array}{l}\text { Estimated time } \\
\text { to harvest }(\mathrm{d})\end{array}$ & Source ${ }^{\mathrm{z}}$ \\
\hline Aristotle $\mathrm{X} 3 \mathrm{R}^{\circledR}$ & $\mathrm{F}_{1}$ hybrid & Untreated & Extra-large, blocky fruit. Thick walls. & 72 to 75 & Seminis \\
\hline California Wonder & Open-pollinated & Organic & $\begin{array}{l}\text { Large blocky fruit, thick-walled. } \\
\text { Flavorful. }\end{array}$ & 75 & Burpee \\
\hline Gourmet & $F_{1}$ hybrid & Untreated & $\begin{array}{l}\text { Thick walls. Fruity sweet flavor. } \\
\text { Medium-large, blocky shape. }\end{array}$ & 65 to 85 & Johnny's \\
\hline Gridiron & $\mathrm{F}_{1}$ hybrid & Untreated & $\begin{array}{l}\text { Early maturing. Extra-large, blocky } \\
\text { fruit with glossy, thick walls. }\end{array}$ & No information & Sakata \\
\hline Islander & $\mathrm{F}_{1}$ hybrid & Untreated & $\begin{array}{l}\text { Thick-fleshed. Mild, slightly sweet taste. } \\
\text { Medium-sized fruit with } 3 \text { lobes. } \\
\text { Transitions from purple, yellow, } \\
\text { orange, and then red. }\end{array}$ & 56 to 81 & Johnny's \\
\hline Jupiter & Open-pollinated & Organic & $\begin{array}{l}\text { Large-sized fruit. Sweet taste. Drought } \\
\text { resistant. Leafy plant canopy. }\end{array}$ & 75 & SESE \\
\hline King Arthur & $\mathrm{F}_{1}$ hybrid & Untreated & $\begin{array}{l}\text { Early production. Big crop. Large, } \\
\text { thick-walled fruit. }\end{array}$ & 59 to 79 & Johnny's \\
\hline PS $09979325 \mathrm{Xl0R}^{\circledR}$ & $\mathrm{F}_{1}$ hybrid & Untreated & $\begin{array}{l}\text { Good size, blocky shape, concentrated } \\
\text { fruit set. }\end{array}$ & 74 & Seminis \\
\hline Red Knight X3R ${ }^{\circledR}$ & $\mathrm{F}_{1}$ hybrid & Untreated & Big, blocky shape. Early to turn red. & 57 to 77 & Johnny's \\
\hline Sweet Chocolate & $\mathrm{F}_{1}$ hybrid & Organic & $\begin{array}{l}\text { Early, cold tolerant. Medium-small } \\
\text { fruit with blunt ends. Medium- } \\
\text { thick flesh. Mild flavor. }\end{array}$ & 58 to 78 & Johnny's \\
\hline Touchdown & $\mathrm{F}_{1}$ hybrid & Untreated & $\begin{array}{l}\text { Continuous setting ability. Excellent } \\
\text { cover. Large to extra-large, uniform, } \\
\text { blocky fruit with thick walls. }\end{array}$ & 72 to 75 & Sakata \\
\hline
\end{tabular}

${ }^{\mathrm{z}}$ Seminis = Seminis Vegetable Seeds, St. Louis, MO; Sakata = Sakata Seed America, Morgan Hill, CA; Burpee = W. Atlee Burpee \& Co., Warminster, PA; Johnny’s = Johnny's Selected Seeds, Winslow, ME; SESE = Southern Exposure Seed Exchange, Mineral, VA.

in this trial was 'California Wonder', which is an older variety that remains popular particularly among amateur growers. However, it has experienced genetic drift with two different varieties recognized (Candole et al., 2012). Released in 1965 by the University of New Hampshire, 'Sweet Chocolate' is an open-pollinated specialty sweet pepper that is brown at maturity (Seed Savers Exchange, 2019).

There is a dearth of pepper trials that compare variety performance under organic production practices, especially in the southeastern United States where pepper is an economically important crop. Therefore, the objective of the study was to evaluate total yield, graded yield, and early yield of 13 commercial pepper varieties available in the United States when grown in an organic system in the southeastern region.

\section{Materials and methods}

Site BACKGround. The study was conducted at the University of
Georgia's UGArden, an organically managed teaching and education farm located in Athens, GA (lat. $33.9519^{\circ} \mathrm{N}$, long $83.3576^{\circ} \mathrm{W}$ ) in 2016 and 2017. Soils at this site are categorized as a well-drained acidic [pH 6.37 (2016) and 6.47 (2017)] Cecil sandy loam soil [CYB2 (USDA, $1968)]$ with $\approx 5 \%$ organic matter. The project site has been operated as a noncertified organic farm since 2010. All production methods were performed to meet the guidelines set forth by the USDA National Organic Program certification standards (7 U.S.C \$6501). To meet crop rotation goals, the experiment was situated in two different fields (i.e., one field in 2016 and a different field in 2017) in very close proximity ( $<100 \mathrm{ft}$ apart) with similar soil characteristics and management practices. Solanaceous crops (Solanaceae) were not grown in these plots in the year preceding the experiment. The site is located $\approx 5$ miles from the University of Georgia
Weather Network, WatkinsvilleHorticulture Research Farm weather station, which monitors daily air temperature and rainfall.

VARIETY SELECTION. The 13 pepper varieties included in this study are listed in Table 1. Variety choices were based on seed catalog descriptions promoting appropriateness for summer/fall production, disease resistance, and/or popularity among growers. Many of these entries, according to their developers, have some level of resistance to bacterial leaf spot, an important disease of bell peppers that may reduce marketable yield.

Experimental design. A replicated comparison of 13 sweet pepper varieties transplanted in midsummer and managed with organic practices was carried out over two growing seasons. Differences in crop yields and days to harvest after transplanting were evaluated while pest and disease issues were monitored. 
The experiment was a randomized complete block design with three replicates. The planting dates were 21 July 2016 and 18 July 2017 . Three harvests were carried out each year, including 26 Sept., 10 Oct., and 24 Oct. 2016 and 10 Sept., 6 Oct., and 25 Oct. 2017. The first harvest was carried out earlier in 2017 compared with 2016 to avoid losses from tropical storm Irma that affected the area with winds up to $50 \mathrm{mph}$ on $11 \mathrm{Sept}$. 2017.

Crop management and data collection were carried out by block. Crops were grown on 3 -ft-wide raised beds on 5 - $\mathrm{ft}$ centers with a northsouth orientation. Each pepper block consisted of two 100-ft-long rows with a 12 -inch in-row and 12 -inch between-row spacing for a total of 20 plants per experimental unit. Footpaths between beds were $\approx 2 \mathrm{ft}$ wide, resulting in $\approx 60 \%$ of the area planted with the pepper crop. If this spacing was extrapolated to 1 acre, we estimate a planting density of $\approx 17,424$ pepper plants per acre $\left(1.5 \mathrm{ft}^{2} /\right.$ plant $)$. Blocks were rerandomized each year.

Site PREPARATION AND CROP MANAGEMENT. A cover crop of spring buckwheat (Fagopyrum esculentum) was sown, flail mowed, and incorporated into the soil 3 to 4 weeks before each summer pepper planting. Lime was applied each year at the time of cover crop seeding (Table 1). Fertilization was based on University of Georgia soil test recommendations. Raised beds were formed using a power take-off (PTO)-driven walk behind tractor and rotary plow (853; BCS America, Portland, OR). White over black totally impermeable film polyethylene plastic mulch $(1.1 \mathrm{mil})$ (Guardian Agricultural Plastics Corp., Tampa, FL) was laid by hand and secured over two lines of drip tape (Aqua-traxx; Toro, Sanford, FL) with emitters every 8 inches and a flow rate of $40 \mathrm{gal} / \mathrm{h}$ per $100 \mathrm{ft}$ of tape.

Transplants were grown onsite in a greenhouse maintained at 70 to $80^{\circ} \mathrm{F}$ nighttime/daytime temperatures. Seeds were sown into 48 -cell packs filled with potting media (Sunshine Natural \& Organic Mix \#l; Sun Gro Horticulture, Agawam, MA). Overhead irrigation was administered by misters the first 3 weeks and then by hand as needed. A $4 \mathrm{~N}-1.3 \mathrm{P}-2.5 \mathrm{~K}$ soluble fish and seaweed fertilizer (AgGrand Organic Series; Amsoil, Superior, WI) was applied once per week from the fourth week after seeding until transplanting at a rate of 2 tablespoons per gallon of water. Seedlings were acclimated to the outside environment 1 week before transplanting to the field. Seedlings were planted at $\approx 8$ weeks after sowing.

Additional fertilizers and soil amendments were incorporated into the soil $\approx 2$ weeks before transplanting peppers (Table 2). Rates were based on the low range of soil test recommendations from the University of Georgia Agriculture and Environmental Services Laboratory (AESL) in Athens. Pre-plant fertilizers included hydrolyzed poultry feathers, potassium sulfate, and boron (Table 2). Plant tissue analysis was conducted by the AESL at the early bloom/fruiting stage $(\approx 8$ weeks after transplanting). Results from these tests indicated that all nutrient concentrations where within recommended ranges and no additional fertilizers were applied. A stake-andweave type trellis system using 4 - $\mathrm{ft}$ tall, l-inch-thick untreated wooden stakes was used to secure the pepper plants upright.

Pest management decisions were based on weekly scouting, and treatment actions were based on organic pest management guidelines when available. The following products were used to manage pest and disease pressure over the 2016 to 2017 seasons: Bacillus thuringiensis (Dipel DF and Xentari DF; Valent Biosciences, Libertyville, IL) for southern armyworms (Spodoptera eridania) and fall armyworms (Spodoptera frugiperda); spinosad (Entrust SC; Dow AgroSciences, Indianapolis, IN) for southern armyworms, fall armyworms, and fire ants (Solenopsis invicta); azadirachtin and pyrethrin (Azera; Valent Biosciences) for green peach aphids (Myzus persicae), southern armyworms, fall armyworms, leaf-footed plant bugs (Leptoglossus sp.), and aphids (Aphidoidea); potassium bicarbonate (Kaligreen; Otsuka AgriTechno Co., Tokyo, Japan) for anthracnose (Glomerella sp.). In 2016, bacterial soft rot (Erwinia carotovora) was present and efforts were made to remove infected fruit from the field as soon as possible to prevent spreading. Also, in 2016, frogeye leafspot (Cercospora capsici) was present the last month of the experiment. It was not treated because organic treatment options were limited, and the harvesting was near completion. And last, in both 2016 and 2017, there was low pressure from southern blight (Sclerotium rolfsii). Efforts were made to remove infected plants and any visible sclerotia from the field as soon as possible to prevent spreading.

SAMPLING PROTOCOLS. Peppers were harvested on three dates each year spanning from September through October. The harvest period began $\approx 2$ months after transplanting. The first harvest was carried out 2 weeks earlier in 2017 compared with 2016 to avoid heavy fruit losses from tropical storm Irma. All fruit deemed a marketable size (i.e., dependent on variety) were harvested regardless of their color. Damaged fruit (e.g., sunscald, insect damage, rot) were not evaluated. Fruit were stored in a $45^{-}{ }^{\circ} \mathrm{F}$ cooler temporarily until sorting and grading occurred. An automated sizing table (Kerian Speed Sizer; Kerian Machines, Grafton, ND) was used to sort the peppers into the following categories: U.S. Fancy (width $\geq 3$ inches and $\geq 3.5$ inches length), No. 1 ( $\geq 2.5$ inch width and length), and No. 2 ( $<2.5$ inch width and length)

Table 2. Pre-plant soil amendments and fertilizer inputs for pepper variety trials on a dry weight basis.

\begin{tabular}{|c|c|c|}
\hline Material $^{\mathrm{z}}$ & Source & Rate $(1 \mathrm{~b} / \mathrm{acre})^{\mathrm{y}}$ \\
\hline Calcium carbonate lime & Lhoist North America, Inc., Fort Worth, TX & 1,105 \\
\hline Hydrolyzed Poultry Feathers (13N-0P-0K) & Mason City By-products, Inc.; Mason City, IA & 1,050 \\
\hline Boron $(10 \%)$ & Cameron Chemicals; Virginia Beach, VA & 10 \\
\hline
\end{tabular}

${ }^{\mathrm{z}}$ The same materials and rates listed were applied each year.

${ }^{y} 1 \mathrm{lb} / \mathrm{acre}=1.1209 \mathrm{~kg} \cdot \mathrm{ha}^{-1}$. 
(USDA, 2005). Subsequently, each category was counted and weighed to assess total marketable yield and average fruit size.

Statistical analysis. Analysis of variance, coefficients of variation, and Fisher's protected least significant difference $(P \leq 0.05)$ were calculated with Stata 15.1 (StataCorp, College Station, TX). Analysis of early yields were for fruit harvested at the first harvest, which was on 26 Sept. 2016 the first year and 10 Sept. 2017 the second year.

\section{Results}

Figure 1 has photos of the harvested fruit, which were generally smaller than conventionally marketed peppers or the company descriptions would indicate (Table 1 ).

The coefficients of variation (CVs) were in line with what should be expected for a field trial. With the exception of fancy fruit, the CVs in 2016 ranged from $19 \%$ to $35 \%$. The fancy fruit had CVs in excess of $100 \%$, which is due to several entries producing no fancy fruit in 2016. In 2017 , the CVs ranged from $13 \%$ to $57 \%$. There were significant treatment by year interactions, so the results are presented separately for each year. Overall, the 2016 growing season was warmer than 2017, including more days in August and September that surpassed $90{ }^{\circ} \mathrm{F}$ (Fig. 2). In addition, 2016 was drier. The total precipitation for the 2016 growing season was 6 inches compared with 16 inches in 2017 (Fig. 2).

In 2016, the analysis of total yield was not significant, for the varieties, according to Fisher's protected least significant difference; however, the overall probability was 0.080 , suggesting that differences might be of particular interest (Table 3). 'Sweet Chocolate' had the highest yield in 2016, but it also had the smallest fruit. The number of 'Sweet Chocolate' fruit harvested was three times that of any of the other entries in the trial (data not shown). With the exception of 'Flavorburst' and 'Islander', all the other entries produced total yields well over 1000 boxes/acre.

In 2016, 'Aristotle X3R ${ }^{\circledR}$ ' had the greatest number of fancy fruit, with 118 boxes/acre, which did not differ from the next three highest yielding entries for this classification. 'King Arthur', 'Touchdown', and 'PS

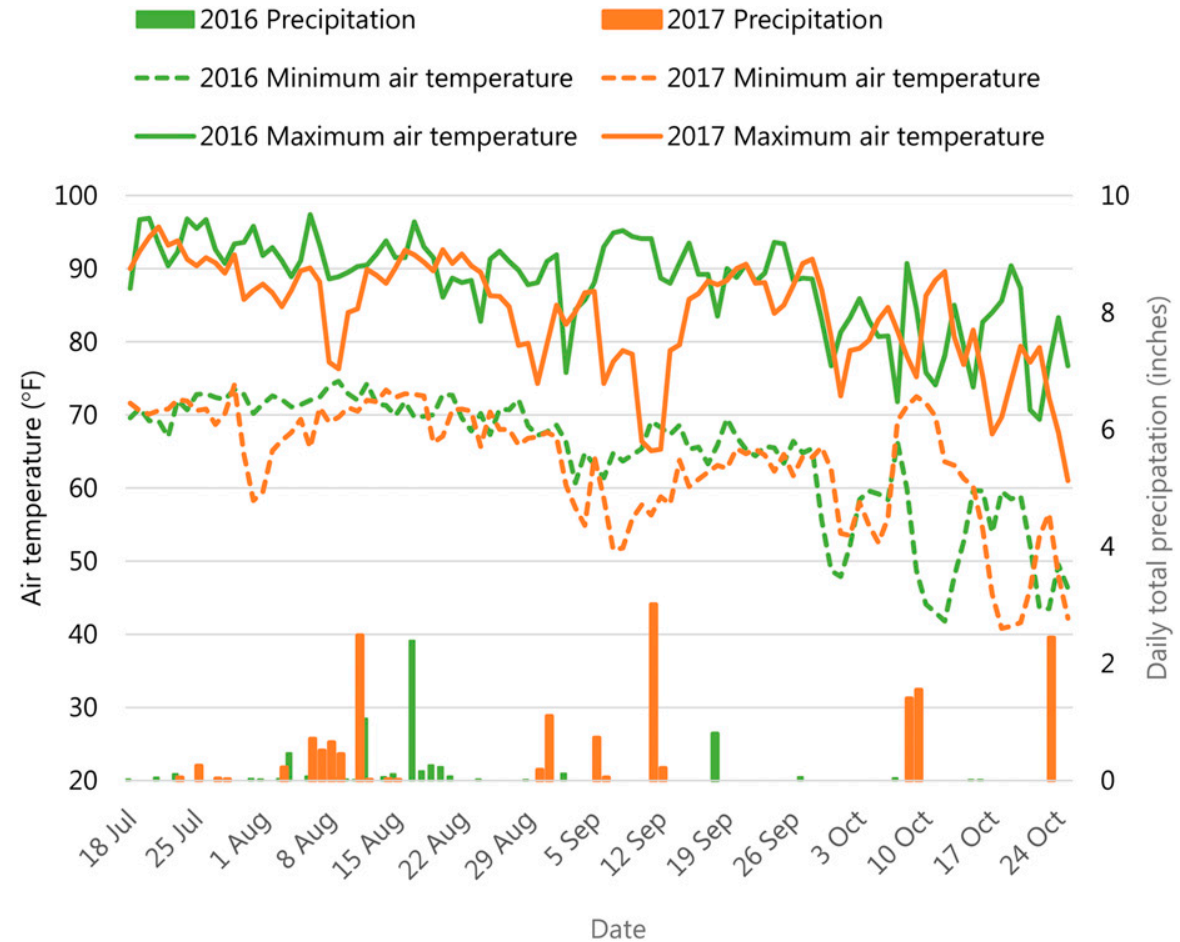

Fig. 2. Average daily minimum and maximum air temperature and total daily precipitation during the 2016 and 2017 seasons. Data from the University of Georgia Weather Network, Watkinsville-Horticulture Research Farm weather station located $\approx 5$ miles $(8.0 \mathrm{~km})$ from the experimental site; $\left({ }^{\circ} \mathrm{F}-32\right) \div 1.8={ }^{\circ} \mathrm{C}$, 1 inch $=2.54 \mathrm{~cm}$.

$09979325 \mathrm{Xl0R}^{\circledR}$, produced significantly fewer fancy fruit than 'Aristotle $\mathrm{X} 3 \mathrm{R}^{\circledR}$. Six of the 13 entries in this trial produced no fancy fruit in 2016.

'Red Knight X3R ${ }^{\circledR}$ ' had the greatest yield of No. 1 fruit $(\geq 2.5$ inches in diameter and length) in 2016, which was not significantly different from any entry except for 'Flavorburst', 'Islander', or 'Sweet Chocolate'. 'Sweet Chocolate' had only 11 boxes/acre of No. 1 fruit, which is not unusual because this is a specialty pepper with much smaller fruit than typical bell peppers.

'Sweet Chocolate' had the greatest yield of No. 2 fruit (<2.5 inches) in 2016 , which was three times the yield of any other entry. 'Islander' had the next highest number of No. 2 fruit, which was greater than 'Aristotle X3R ${ }^{\circledR}$ ', 'California Wonder', and 'Gridiron'. Generally, varieties with low numbers of No. 2 fruit have higher numbers of fancy and No. 1 fruit.

In 2016, fruit harvested on 26 Sept. was considered early yield. Neither the early total yield nor the yield of fancy fruit had significant differences in 2016. 'Red Knight $\mathrm{X}^{3} \mathrm{R}^{\circledR}$ ' had the greatest early yield of No. 1 fruit, but did not differ from any variety except for 'Flavorburst', 'Islander', and 'Sweet Chocolate'. 'Sweet Chocolate' had the greatest early yield of No. 2 fruit, almost four times more than any other entry. 'Islander' had the next highest early yield of No. 2 fruit, which was greater than 'California Wonder', 'Touchdown', and 'Gridiron'.

The fruit weight in 2016 ranged from 1.4 to $6.3 \mathrm{oz}$. The largest fruit overall was with 'Gridiron', which was significantly larger than 'Touchdown' at $4.4 \mathrm{oz}$.

In 2017 , the greatest total yield was with 'Aristotle $\mathrm{X} 3 \mathrm{R}^{\circledR}$ ' with 2087 boxes/acre, which was not significantly greater than 'Gridiron', 'King Arthur', 'Flavorburst', 'Blitz', 'Touchdown', or 'PS $099793325 \mathrm{XlOR}^{\circledR}$, (Table 4). In contrast 'Gourmet' had the lowest total yield in 2017 and did not differ from 'California Wonder', 'Sweet Chocolate', 'Islander', and 'Jupiter'.

The yield of fancy fruit in 2017 was dramatically greater than in 2016. The greatest number of boxes per acre of fancy fruit in 2017 was led by 'Blitz', with 768 boxes/acre, which was significantly greater than 'Touchdown' 
Table 3. Organic pepper variety trial of total and early yields of total, fancy, No. 1, and No. 2 yields with early yield harvested on 26 Sept. 2016.

\begin{tabular}{|c|c|c|c|c|c|c|c|c|c|}
\hline \multirow[b]{3}{*}{ Variety } & \multicolumn{4}{|c|}{ Total yield ${ }^{\mathrm{z}}$} & \multicolumn{4}{|c|}{ Early yield } & \multirow{3}{*}{$\frac{\text { Fruit wt }}{(\mathrm{oz})^{\mathrm{y}}}$} \\
\hline & Total & Fancy & No. 1 & No. 2 & Total & Fancy & No. 1 & No. 2 & \\
\hline & \multicolumn{8}{|c|}{ (boxes/acre) } & \\
\hline Aristotle $\mathrm{X} 3 \mathrm{R}^{\circledR}$ & 1,135 & 118 & 714 & 303 & 413 & 55 & 258 & 100 & 5.1 \\
\hline Blitz & 1,279 & 87 & 863 & 329 & 504 & 37 & 358 & 109 & 5.7 \\
\hline California Wonder & 1,284 & 0 & 998 & 286 & 462 & 0 & 377 & 86 & 3.9 \\
\hline Flavorburst & 961 & 0 & 526 & 435 & 346 & 0 & 213 & 132 & 2.8 \\
\hline Gourmet & 1,263 & 0 & 800 & 462 & 436 & 0 & 265 & 171 & 3.0 \\
\hline Gridiron & 1,296 & 90 & 967 & 239 & 502 & 33 & 389 & 80 & 6.3 \\
\hline Islander & 850 & 0 & 316 & 533 & 326 & 0 & 137 & 188 & 2.4 \\
\hline Jupiter & 1,194 & 0 & 835 & 360 & 439 & 0 & 321 & 118 & 4.0 \\
\hline King Arthur & 1,113 & 23 & 772 & 318 & 402 & 4 & 287 & 111 & 5.2 \\
\hline PS $09979325 \mathrm{Xl0R}^{\circledR}$ & 1,113 & 3 & 729 & 380 & 380 & 2 & 245 & 134 & 3.6 \\
\hline Red Knight X3R ${ }^{\circledR}$ & 1,397 & 51 & 1,009 & 337 & 542 & 12 & 397 & 133 & 5.7 \\
\hline Sweet Chocolate & 1,780 & 0 & 11 & 1,768 & 723 & 0 & 1 & 723 & 1.4 \\
\hline Touchdown & 1,309 & 19 & 971 & 320 & 465 & 10 & 371 & 85 & 4.4 \\
\hline Coefficient of variation & $23 \%$ & $163 \%$ & $26 \%$ & $29 \%$ & $26 \%$ & $186 \%$ & $32 \%$ & $35 \%$ & $19 \%$ \\
\hline $\operatorname{LSD}(P \leq 0.05)^{\mathrm{x}}$ & NS & 83 & 316 & 226 & NS & NS & 152 & 98 & 1.3 \\
\hline
\end{tabular}

Table 4. Organic pepper variety trial of total and early yields of total, fancy, No. 1 , and No. 2 yields with early yield harvested on 10 Sept. 2017.

\begin{tabular}{|c|c|c|c|c|c|c|c|c|c|}
\hline \multirow[b]{3}{*}{ Variety } & \multicolumn{4}{|c|}{ Total yield $^{\mathrm{z}}$} & \multicolumn{4}{|c|}{ Early yield } & \multirow{3}{*}{$\frac{\text { Fruit wt }}{(o z)^{y}}$} \\
\hline & Total & Fancy & Fruit wt & No. 2 & Total & Fancy & No. 1 & No. 2 & \\
\hline & \multicolumn{8}{|c|}{ (boxes/acre) } & \\
\hline Aristotle $\mathrm{X} 3 \mathrm{R}^{\circledR}$ & 2,087 & 572 & 1,368 & 146 & 887 & 146 & 699 & 42 & 5.5 \\
\hline Blitz & 1,933 & 768 & 1,071 & 94 & 606 & 128 & 461 & 18 & 5.3 \\
\hline California Wonder & 1,309 & 68 & 1,029 & 212 & 169 & 0 & 113 & 55 & 3.4 \\
\hline Flavorburst & 2,014 & 116 & 1,560 & 338 & 820 & 32 & 674 & 113 & 3.5 \\
\hline Gourmet & 1,298 & 64 & 993 & 241 & 456 & 2 & 339 & 115 & 3.4 \\
\hline Gridiron & 2,070 & 624 & 1,257 & 189 & 744 & 109 & 603 & 32 & 5.1 \\
\hline Islander & 1,528 & 35 & 1,220 & 272 & 764 & 6 & 643 & 115 & 3.1 \\
\hline Jupiter & 1,593 & 266 & 1,129 & 198 & 389 & 3 & 305 & 81 & 4.1 \\
\hline King Arthur & 2,063 & 585 & 1,209 & 269 & 716 & 68 & 604 & 44 & 4.9 \\
\hline PS $09979325 \mathrm{Xl0R}^{\circledR}$ & 1,838 & 558 & 1,209 & 70 & 679 & 71 & 593 & 15 & 4.9 \\
\hline Red Knight X3R ${ }^{\circledR}$ & 1,670 & 352 & 1,089 & 229 & 713 & 146 & 524 & 43 & 5.1 \\
\hline Sweet Chocolate & 1,520 & 13 & 238 & 1,269 & 517 & 0 & 23 & 494 & 2.1 \\
\hline Touchdown & 1,884 & 434 & 1,260 & 190 & 804 & 84 & 643 & 76 & 4.9 \\
\hline Coefficient of variation & $15 \%$ & $47 \%$ & $18 \%$ & $29 \%$ & $21 \%$ & $57 \%$ & $22 \%$ & $53 \%$ & $13 \%$ \\
\hline $\operatorname{LSD}(P \leq 0.05)^{\mathrm{x}}$ & 367 & 231 & 285 & 118 & 194 & 50 & 151 & 72 & 0.8 \\
\hline
\end{tabular}

with 434 boxes/acre. 'Sweet Chocolate', which is smaller than typical bell peppers, had the lowest amount of fancy fruit in 2017. The top five entries in 2017 had more than 500 boxes/ acre of fancy fruit.

No. I sized peppers generally had the most yield among the size classes in 2017. 'Flavorburst' had the greatest amount of No. 1 fruit and differed significantly from all other varieties except 'Aristotle $\mathrm{X} 3 \mathrm{R}^{\circledR}$ '. 'Sweet Chocolate' had the lowest amount of No. 1 fruit and it was significantly less than any other entry. Eleven of the 13 varieties in the 2017 trial had more than 1000 boxes/acre of No. 1 fruit.

Not unsurprising, 'Sweet Chocolate' had the greatest amount of No. 2 fruit in 2017 with 1269 boxes/acre. This was almost four times more fruit than any other variety in the trial. 'PS $099793325 \mathrm{XlOR}^{\circledR}$ ' and 'Blitz' had less than 100 boxes/acre of No. 2 fruit in 2017.

Early yield in 2017 was harvested on 10 Sept. 2017 , which was $\approx 2$ weeks earlier than in 2016. 'Aristotle $\mathrm{X}_{3} \mathrm{R}^{\circledR}$, had the greatest amount of early total yield, with 887 boxes/acre, which was significantly greater than 'Blitz' with 606 boxes/acre. 'California Wonder' 
had the lowest early total yield, which was significantly less than any other variety in the 2017 experiment.

Early fancy fruit yield was led by 'Aristotle $\mathrm{X} 3 \mathrm{R}^{\circledR}$ ' and 'Red Knight $\mathrm{X} 3 \mathrm{R}^{\circledR}$, with 146 boxes/acre, which did not differ from 'Blitz' or 'Gridiron' with 128 and 109 boxes/acre, respectively. The five varieties with the lowest number of early fancy fruit in 2017 all had fewer than 10 boxes/ acre with two entries, 'Sweet Chocolate' and 'California Wonder' having no early fancy fruit.

'Aristotle $\mathrm{X} 3 \mathrm{R}^{\circledR}$ ' had the greatest amount of early No. 1 fruit in 2017 with 699 boxes/acre, which was significantly greater than 'Red Knight $\mathrm{X} 3 \mathrm{R}^{\circledR}$ ' with 524 boxes/acre. Both 'California Wonder' and 'Sweet Chocolate' had the lowest yield of No. 1 fruit in 2017 and were both significantly less than any of the other varieties.

'Sweet Chocolate' had the greatest early yield of No. 2 fruit in 2017, with 494 boxes/acre, which was four times greater than the next highest yielding variety for No. 2 fruit. The least number of early No. 2 yield in 2017 was with 'PS 099793325 $\mathrm{XIOR}^{\circledR}$, with 15 boxes/acre, which was significantly less than 'Flavorburst' with 113 boxes/acre.

'Sweet Chocolate', not unexpectedly, had the smallest fruit in 2017 at $2.1 \mathrm{oz}$, which was significantly smaller than any other variety in the trial. The largest fruit in 2017 was 'Aristotle $\mathrm{X} 3 \mathrm{R}^{\circledR}$ ' with an average fruit weight of $5.5 \mathrm{oz}$, which was significantly greater than 'Jupiter', with an average fruit size of $4.1 \mathrm{oz}$.

\section{Discussion and conclusions}

Twelve of the 13 varieties in this trial were typical bell peppers. 'Sweet Chocolate' was the exception, as a small sweet pepper that is dark brown at maturity. This is reflected with its relatively high yield of small fruit (i.e., No. 2). These types of small sweet peppers marketed at full maturity have become very popular. However, usually these are yellow, orange, or red at maturity.

The top five entries for fancy fruit in both 2016 and 2017 included 'Aristotle $\mathrm{X} 3 \mathrm{R}^{\circledR}$,' 'Gridiron', 'Blitz', and 'King Arthur', with 'Red Knight $\mathrm{X} 3 \mathrm{R}^{\circledR}$ ' in 2016 and 'PS 09979325 $\mathrm{XlOR}^{\circledR}$, in 2017 also in this group. Large blocky bell peppers, which the fancy fruit represent, are the most desirable size and all of these varieties do well in this category. Two of these entries, 'Aristotle X3R ${ }^{\circledR}$ ' and 'Gridiron', had both early yields and lots of fancy fruit. 'Flavorburst' also had early yields and high total yields, but not as many fancy fruit as 'Aristotle $\mathrm{X} 3 \mathrm{R}^{\circledR}$ ' or 'Gridiron'. 'Aristotle X3R ${ }^{\circledR}$ ' and 'Gridiron' were among the top five entries in a trial of bell peppers conducted in 2014 under conventional production practices (Boyhan et al., 2015).

'Aristotle $\mathrm{X} 3 \mathrm{R}^{\circledR}$ ', a popular variety throughout the pepper industry, produced in these trials 1135 to 2087 boxes/acre, which was comparable to a trial in Ohio where they produced 1194 boxes/acre (Gahler and Hofelich, 2017). Overall, the Ohio trial yields averaged 1214 boxes/acre, which is in line with these trials. In a high-tunnel experiment in New Hampshire, 1643 to 2379 boxes/ acre were produced, which is more than in these trials (Sideman, 2016). This may indicate the value of using high tunnels for pepper production.

The average total yield was 1229 and 1754 boxes/acre for 2016 and 2017 , respectively. These yields are favorable in comparison with overall U.S. production of 1343 boxes/acre in 2015 (Biswas et al., 2017). 'Gridiron', 'Blitz', and 'Touchdown' were consistently in the top six entries for total yield.

Lower yields in 2016 may have been a result of greater than ideal temperatures for fruit setting (i.e., $>90{ }^{\circ} \mathrm{F}$ daytime or $>70{ }^{\circ} \mathrm{F}$ nighttime) and/or the higher incidence of disease, including frogeye leafspot that resulted in some leaf defoliation toward the end of the 2016 season (Penezny et al., 2003). Although we cannot make any conclusive statements about these effects because we did not examine these factors thoroughly as part of this study, there were no apparent patterns in terms of disease incidence by variety in the field. In addition, techniques such as using shadecloth to lower the ambient environment around pepper plants in Georgia have been used successfully and may help sustain ideal temperatures during fruit set and improve yields (Diaz-Perez, 2014). In 2017, the top five yielding varieties together yielded 2033 boxes/acre, which is considerably higher than U.S. production in 2015 .
Typically, organic produce sells for prices $10 \%$ to $100 \%$ more than the conventional equivalent (Elliott, 2011; Oberholtzer et al., 2005; USDA, 2017). The average price for U.S. field-grown conventional bell peppers according to USDA terminal markets during the 2018 summer/ fall season was $\$ 11.00$ to $\$ 22.00$ per box and $\$ 38.00$ to $\$ 42.00$ for U.S. field-grown organic bell peppers, indicating price premium on the higher end of the spectrum (USDA, 2018). Colored (e.g., red, orange, yellow) peppers as well as greenhouse-grown peppers received higher prices than green or field-grown peppers in both organic and conventional categories (Offner, 2018; USDA, 2018). Assuming a $30 \%$ greater return per box of organic peppers would result in a price of $\$ 17.58$ and return per acre for the 2016 and 2017 trials of $\$ 21,605$ and $\$ 30,835$, respectively. Although organic production is generally more expensive than conventional because of the greater cost of weed control and other inputs, it appears based on these numbers that organic bell peppers would be a viable endeavor (Brumfield et al., 2000).

Along with large size, early yield is important to growers, generally because it results in better prices. Although there were no significant differences for total early yield in 2016, 'Sweet Chocolate' had the highest numeric yield with a probability of 0.058 , which is close to the declared significance level of 0.05 . When 'Sweet Chocolate' was excluded from the analysis, the probability value was 0.587 . In 2017 , there were significant differences in early total yield with 'Aristotle $\mathrm{X} 3 \mathrm{R}^{\circledR}$ ' and 'Gridiron' among the top five highest yielding for early yield, whereas 'Sweet Chocolate' was not among this group. More importantly, 'Aristotle $\mathrm{X} \mathrm{R}^{\circledR}$ ', 'Red Knight $\mathrm{X} 3 \mathrm{R}^{\circledR}$, 'Blitz', 'Gridiron', and 'Touchdown' were the top five yielding for early fancy-sized peppers. These results are similar to an earlier trial of sweet bell peppers grown under conventional conditions in which 'Aristotle $\mathrm{X} 3 \mathrm{R}^{\circledR}$ ', 'Blitz', and 'Gridiron' were among the top performers (Boyhan et al., 2015).

In conclusion, these results should help organic growers make informed choices about variety selection based on what is most important 
to their markets: total yield, fancy yield, or early yield. Small, uniquely colored specialty peppers, such as 'Sweet Chocolate', may also be considered for niche markets. Based on this study, organic pepper production is a viable crop in Georgia. Yields were comparable to conventional pepper production with the potential of superior returns on investment.

\section{Literature cited}

Biswas, T., Z. Guan, and F. Wu. 2017. An overview of the U.S. bell pepper industry. 28 Feb. 2019. <https://gcrec.ifas.ufl. edu/media/gcrecifasufledu/images / zhengfei/FE-Bell-Pepper.pdf>.

Boyhan, G., T. Coolong, and C. McGregor. 2015. Evaluation of pepper varieties for production in Georgia, p. 73-74. In: T. Coolong (ed.). 2014/2015 Univ. Georgia Veg. Crops Res. Rpt. Univ. Georgia, Annu. Publ. 115.

Boyhan, G.E. and S.P. Stone. 2016. Breeding for organic and sustainable production, p. 123-136. In: D. Nandwani (ed.). Organic farming for sustainable agriculture. Springer Intl. Publ., Basel, Switzerland.

Brumfield, R.G., A. Rimal, and S. Reiners. 2000. Comparative cost analyses of conventional integrated crop management and organic methods. HortTechnology 10:785-793.

Candole, B.L., P.J. Conner, C. McGregor, V. Waters, and P. Ji. 2012. The disease reactions of heirloom bell pepper "California Wonder" to Phytophthora capsici. Agro Sci. 3:417-424.

Castellanos, J.Z., P. Cano-Rios, E.M. Garcia-Carrillo, V. Olalde-Portugal, P. Preciado-Rangel, J.L. Rios-Plaza, and J.L. Garcia-Hernandez. 2017. Hot pepper (Capsicum annuum L.) growth, fruit yield, and quality using organic sources of nutrients. Compost Sci. Util. 25:S70 S77.

Cesar, M.N.Z., R.D.D. Ribeiro, P.D. de Paula, J.C. Polidoro, T.D. Manera, and J.G.M. Guerra. 2007. Performance of sweet pepper under organic cultivation, submitted to intercropping with crotalaria and branch pruning. Hort. Bras. 25:322-326.

Chellemi, D.O. and E.N. Rosskopf. 2004. Yield potential and soil quality under alternative crop production practices for fresh market pepper. Renew. Agr. Food Syst. 19:168-175.

Delate, K., C. Cambardella, and A. McKern. 2008. Effects of organic fertilization and cover crops on an organic pepper system. HortTechnology 18:215-226.
Diaz-Perez, J. 2014. Bell pepper (Capsicum annum L.) crop as affected by shade level: Fruit yield, quality, and postharvest attributes, and incidence of phytophthora blight (caused by Phytophthora capsici Leon.). HortScience 49:891-900.

Duman, I., U. Aksoy, A. Altndisli, and Ö.L. Elmac. 2018. A long-term trial to determine variations in the yield and quality of a processing type pepper ( Capsicum annumm L. cv. Yalova yaglik-28) in organic and conventional farming systems. Org. Agr. 8:69-77.

Elliott, S. 2011. How much more does organic food cost and why? 29 Apr. 2019. <https://money.howstuffworks.com/ personal-finance/budgeting/how-muchmore-does-organic-food-cost-and-why. htm>.

Elmann, A., A. Garra, S. Alkalai-Tuvia, and E. Fallik. 2016. Influence of organic and mineral-based conventional fertilization practices on nutrient levels, antiproliferative activities and quality of sweet red peppers following cold storage. Isr. J. Plant Sci. 63:51-57.

Gahler, A.M. and M. Hofelich. 2017. Northern Ohio pepper variety trial. Ohio Agr. Res. Dev. Ctr. Rpt., Ohio State Univ., Fremont.

Gragera, J., J. Gutiérrez, A. Esteban, E. Giraldo, J.A. González, and C.G. Gil. 2008. Evaluation of Spanish landraces of pepper cultivated in Extremadura (Spain) under organic agriculture techniques, Modern variety breeding for present and future needs. Proc. 18th EUCARPIA Gen. Congr., Valencia, Spain, 9-12 Sept. 2008. p. 704-708.

Gragera-Facundo, J., C. Daza-Delgado, C.G. Gil-Torralvo, J.M. Gutiérrez-Perera, and A. Esteban-Perdigón. 2012. Comparing the yield of three pepper cultivars in two growing systems, organic and conventional, in Extremadura (Spain). Acta Hort. 933:131-135.

Johnny's Selected Seed. 2019. Johnny's Selected Seed. 7 Mar. 2019. <https://www. johnnyseeds.com>.

Jokela, D. and A. Nair. 2016. Effects of reduced tillage and fertilizer application method on plant growth, yield, and soil health in organic bell pepper production. Soil Tillage Res. 163:243-254.

Juroszek, P. and H. Tsai. 2009. Yields of organically grown sweet pepper cultivars and lines during the hot-wet and cool-dry season in the tropics. HortTechnology 19:418-422.

Kemble, J.M. (ed.). 2019. Southeastern U.S. vegetable crop handbook. Meister Media Worldwide, Willoughby, OH.
Lammerts van Buren, E.T., L. Jones, K.M. Tamm, J.R. Murphy, J.R. Myers, and C. Leifert. 2011. The need to breed crop varieties suitable for organic farming using wheat, tomato and broccoli as examples: A review. NJAS Wagening. J. Life Sci. 58:193-205.

Lopez, A., J. Fenoll, P. Hellin, and P. Flores. 2013. Physical characteristics and mineral composition of two pepper cultivars under organic, conventional and soilless cultivation. Scientia Hort. 150: 259-266.

Oberholtzer, L., C. Dimitri, and C. Greene. 2005. Price premiums hold on as U.S. organic produce market expands. U.S. Dept. Agr., Econ. Res. Serv. VGS308-1.

Offner, J. 2018. Growers increase organic bell pepper production. 24 Sept. 2019. <https://www.thepacker.com/article/ growers-increase-organic-bell-pepperproduction>.

Oxley, K.L., D. Loewen, and C.L. Rivard. 2016. Evaluation of hybrid bell pepper varieties for high tunnel production in Kansas. 24 Sept. 2019. <http:// hightunnels.org/wp-content/uploads/ 2016-KSU-Bell-Pepper-Variety-TrialReport.pdf>.

Penezny, K., P.D. Roberts, J.F. Murphy, and N.P. Goldberg. 2003. Compendium of pepper diseases. Amer. Phytopathol. Soc., St. Paul, MN.

Pimenta, S., D. Menezes, D.G. Neder, R.A. Melo, A.L.R. Araujo, and E.A.A. Maranhao. 2016. Adaptability and stability of pepper hybrids under conventional and organic production systems. Hort. Bras. 34:168-174.

Ribes-Moya, A.M., M.D. Raigon, E. Moreno-Peris, A. Fita, and A. RodriguezBurruezo. 2018. Response to organic cultivation of heirloom Capsicum peppers: Variation in the level of bioactive compounds and effect of ripening. PLoS One 13:11.

Sakata Seed. 2018. Featured products. 7 Mar. 2019. <https://sakatavegetables. com>.

Seed Savers Exchange. 2019. Sweet Chocolate pepper. 19 Apr. 2019. <https://www. seedsavers.org/sweet-chocolate-organicpepper $>$.

Seminis Vegetable Seeds. 2018. PS 09979325 with Xl0R®. 19 Apr. 2019. <http://www.seminis-us.com/product/ps09979325-with-xl0r/142>.

Sideman, B. 2016. High tunnel pepper variety trial, 2015. 24 Sept. 2019. <https:// extension.unh.edu/resources / files / Resource005720_Rep8006.pdf>. 
Silva, E. and D. Bruce. 2016. Red pepper trial results. 24 Sept. 2019. <http://www. uworganic.wisc.edu/wp-content/ uploads /2017/02/Pepper-Trial-ResultsFlyer.pdfs.

Totally Tomatoes. 2019. Jupiter pepper. 19 Apr. 2019. <https://www.totallytomato. com/P/03171/Jupiter+Pepper>.

U.S. Department of Agriculture. 2019. Vegetables 2018 summary. 4 May 2019. <https://downloads.usda.library.cornell. edu/usda-esmis / files /02870v86p/ gm80j322z/5138jn50j/vegean 19.pdf>.

U.S. Department of Agriculture. 1968. Web soil survey. 12 June 2019. <https:// websoilsurvey.nrcs.usda.gov/app $/>$.

U.S. Department of Agriculture. 2005. Sweet peppers grades and standards. 13
June 2019. <https://www.ams.usda. gov/grades-standards/sweet-peppersgrades-and-standards $>$.

U.S. Department of Agriculture. 2017. 2016 Certified organic survey - Georgia. 24 Sept. 2019. <https://www.nass.usda. gov/Surveys/Guide_to_NASS_Surveys/ Organic_Production/2016_State_ Publications/GA.pdf>.

U.S. Department of Agriculture. 2018. Weekly advertised fruit \& vegetables retail prices for peppers, bell type in the southeast U.S. 5 May 2019. <https:// marketnews.usda.gov/mnp/fv-reportconfig-stepl type $=$ termPrice $>$.
U.S. Food and Drug Administration. 2015. Bell and chile peppers. 29 May 2019. <https://www.wifss.ucdavis.edu/wpcontent/uploads/2016/10/Peppers_ PDF.pdf>.

Wolfe, K. and K. Stubbs. 2018. 2017 Georgia farm gate value report. Univ. Georgia Ctr. Agribusiness Econ. Dev. Publ. AR-18-01.

Wyatt, L.E., A.R. Dunn, M. Falise, S. Reiners, M. Jahn, C.D. Smart, and M. Mazourek. 2013. Red harvest yield and fruit characteristics of Phytophthora capsici-resistant bell pepper inbred lines in New York. HortTechnology 23:356363. 